\title{
Learning for the Future? Effects of Education for Sustainable Development (ESD) on Teacher Education Students
}

\author{
Klas Andersson ${ }^{1, *}$, Sverker C Jagers ${ }^{1,2}$, Annika Lindskog ${ }^{3}$ and Johan Martinsson ${ }^{1}$ \\ 1 Department of Political Science, University of Gothenburg, Sprängkullsgatan 19, P.O. Box 711, \\ Gothenburg SE-405 30, Sweden; E-Mails: sverker.jagers@pol.gu.se (S.C.J.); \\ johan.martinsson@pol.gu.se (J.M.) \\ 2 Political Science Unit, Luleå University of Technology, Luleå SE-971 87, Sweden \\ 3 Department of Pedagogical, Curricular, Professional Studies, University of Gothenburg, \\ P.O. Box 100, Gothenburg SE-405 30, Sweden; E-Mail: annika.lindskog@ped.gu.se \\ * Author to whom correspondence should be addressed; E-mail: klas.andersson@pol.gu.se; \\ Tel.: +46-31-786-4673; Fax: +46-31-786-1895.
}

Received: 18 October 2013; in revised form: 13 November 2013 / Accepted: 20 November 2013 / Published: 2 December 2013

\begin{abstract}
Currently, politicians, university representatives, scholars and leading NGOs share a strong belief in the ability of educational systems to generate positive attitudes to sustainable development (SD) among citizens, with the idea of Education for Sustainable Development (ESD) as perhaps the most apparent expression of this conviction. The aim of this paper is to investigate whether ESD might have the intended effects on teacher education students. More specifically, we account for the results from a panel study on the effects of a course on SD held in autumn 2010 at the University of Gothenburg $(n=323)$ on teacher education students. The surveys consisted of questions about the students' concerns about various issues, including issues related to SD, and their attitudes towards $\mathrm{SD}$ and views of moral obligations to contributing to SD. The study included a control group $(n=97)$ consisting of students from the teacher-training programme at University West, which had not and did not include ESD. We find positive effects of ESD on almost all attitudes and perceptions, including e.g., personal responsibility in relation to SD and willingness to contribute to SD, while there is no noticeable effect in the control group. We conclude the paper by discussing the implications of our results for the idea of ESD in teacher training programmes at Swedish higher education institutions.
\end{abstract}


Keywords: sustainable development; education; environment; teacher training

\section{Introduction}

Many politicians, university representatives, scholars and leading NGOs currently share a belief in the ability of educational systems to generate positive attitudes to Sustainable Development (SD) among citizens [1]. The concept of Education for Sustainable Development (ESD) is perhaps the most apparent expression of this conviction. The central idea behind ESD is that the educational system can be more powerful in promoting changes than regulatory and market-based systems (e.g., legislation and environmental taxes), when it comes to forming future generations of citizens who are either willing to change their attitudes and behaviour, or else at least accept policies aimed at steering society in a more sustainable direction. In this vision, schools, teachers and the institutions that educate the next generation of teachers can be seen as a trinity carrying rather heavy expectations from various groupings concerned with SD. Even if it appears that many are putting their faith in ESD and the trinity, our impression is that research in this field is surprisingly scant. For example, although the expectations are high we find a limited literature investigating whether the trinity actually can affect the values, beliefs and norms regarding SD among future teachers and, if so, under what conditions.

We do, however, know that politicians have strong confidence in teachers' ability to put politicians' intended educational policies, such as an increased awareness of SD, into practice [2]. However, is ESD really useful for this particular purpose? Further, hardly any scientific publications are concerned with whether variation in content and organisation of ESD in teacher education programmes has different effects on future teachers' values, beliefs and norms. From our point of view, there is room for conducting more effect studies [3] on the impact of ESD in teacher education. In this paper, we therefore focus on whether teacher education programmes, that include education for SD, influence teacher students. The overall purpose of the paper is to illuminate whether participating in a teacher education course designed to provide the tools needed to teach about SD can generate pro-SD beliefs and norms among future teachers.

We do this by using a field study approach carried out in 2010/2011 at the teacher education programme at two different Swedish universities. More specifically, the study included a group of teacher students at the University of Gothenburg $(n=323)$ participating in a teacher education course on SD. Before and after the course, the students completed surveys with questions about various issues, including issues related to, SD and the students' attitudes to SD, views of moral obligations to contributing to SD and preferred political route to achieve SD. The study also included a control group $(n=97)$ consisting of students from the teacher education programme at University West, which did not include ESD in their programme at the time.

The paper is organised as follows. In Section 1, we review previous research on factors affecting individuals' attitudes and perceptions regarding SD issues. In this theoretical discussion we review research on educational effects, psychological determinants of everyday pro-environmental behaviour and the institutional theoretical approach that organisations influence attitudes and behavior. We also use the different theoretical approaches to derive the two specific hypotheses. In Section 2, we 
introduce the field study, discussing the independent variable, i.e., the courses in the programmes, and the operationalisation of the dependent variables. In Section 3, we present the results. In the concluding section of the paper, we discuss our main findings, namely the consistently significant effects on almost all attitudes and perceptions that we find in the treatment, group and the implications of our results for the large number of new teacher training programmes that are currently being developed at Swedish higher education institutions.

\subsection{On Education for SD in the Swedish School System}

The idea that ESD has positive effects in terms of behavioural changes benefiting social, economic and ecological sustainability in a population can be traced back to the United Nations Environment and Development Conference in Johannesburg in 2002. There it became clear that SD cannot be achieved solely by traditional means of control such as legislation and market-based policy instruments. Rather, for such a development to take place and be sustained, it was argued that fundamental changes in values and norms among citizens are needed [4-6].

This theory has had a major impact in many countries both in international agreements, state government investigations and politically decided investments in education (such as UNESCO, UNECE (United Nations Economic Commission for Europe), Baltic 21E, an agenda 21 for ESD in the Baltic region). In a Swedish context, an official report from the Swedish Government, SOU 2004:104 [6], for example states that "learning is a prerequisite for people to meet the challenges facing the world. What people learn and how they put it into action is crucial for a sustainable development to be possible". For this reason, "education for sustainable development aims to conquer the learning ability and willingness to work towards a sustainable development locally and globally" [6].

This belief has formulated policy objectives for learning at many levels. The Swedish government's communication (2005:68) [7] for example states that "it is important that sustainable development perspectives permeate all levels of education and all learning. The goal is that knowledge about sustainable development should convey a message, but above all it should stimulate active participation and critical thinking about building a sustainable society". These ideas have also been applied on higher education. Since 2006 all Swedish higher education programmes are explicitly required to "promote sustainable development".

We do not address whether it is desirable for education to be informed by and ought to promote SD; to us, this is an ideological issue rather than a scientific one. However, what is a scientific issue - and also a very relevant one - is whether we can expect that the road Sweden and many other countries $[1,2]$ have embarked upon (i.e., to use higher education such as teacher education in order to, in a direct fashion, make value-based and behavioural changes that are proclaimed as necessary among (now young) citizens, and indirectly when the teacher students begin practicing their profession) will have the intended effects. The hypothesis $\mathrm{H}_{1}$ tested in the study is formulated as:

$\mathrm{H}_{1}$ Participating in a teacher education course designed to provide the tools needed to teach about SD generates pro-SD beliefs and norms among the teacher students. 


\subsubsection{Educational Effects of ESD among Teachers}

In educational research, a large number of wide-ranging studies have investigated pupils' understandings of sustainability concepts [8-14] and how these understandings take part in on-going learning [15-17] and in environmental ethics [18,19]. In some way, these studies are related to effect-orientated correlational and experimental studies on so-called process-product research [20,21], where the process is seen as what the teachers and students did in the classroom and the product consists of what the students have learned. Since the 1990s, research designed lessons [22-24] and the methods of so called lesson and learning studies have increased significantly in educational science[25-28].

There are a growing number of studies on teachers' relations to ESD. The research in this field has shed light on teachers' understanding of concepts related to SD [29-31]. There has been less focus on the effects of teacher education programmes on teachers' values, beliefs and norms regarding SD. The methods used have predominantly been qualitative and the aim has usually been to create typologies of teachers' different ways of conceptualising and approaching ESD in their teaching [32]. However, what determines this conceptualising has not been the primary object of investigation. Parallel to this research, though not necessarily orientated towards ESD, is the research on teachers' views of learning, teaching and the teaching content. In this research it is assumed that the teachers' ideas about teaching, or the teaching content, ultimately influence the teaching practice. The conjecture made is that teachers' view of, for instance, mathematics is important because it tends to influence the way the students will teach mathematics [33]. A strong interest in issues concerning the subject matter can influence the way a teacher interprets the importance of informing pupils about the issues in question. Of course, there is also a massive literature in higher education concerning teaching effects on content knowledge, engagement and attendance. For instance, in 2011 the Nobel Prize winner in physics, Carl Wieman and colleagues, presented a study showing that a more interactive teaching strategy in higher education physics, including reasoning and problem solving, has a strong effect on students' engagement and knowledge [34].

Even though conceptions of SD among pupils and understandings of ESD concepts among teachers have been investigated, little is known about the impact of higher education on teacher education students' perceptions of pro-SD beliefs and norms. Considering the fact that teachers might be key players in the educational policies towards a SD among citizens, this is unexpected.

Though what makes a teacher student change her beliefs, norms and attitudes regarding SD? This is of course a more complicated matter compared with the task of exclusively observing a possible attitude change due to a teacher education course. As referred to above, scholars interested in teachers' beliefs and views of learning outline that an initial intense interest in the subject matter can impact how teacher education students implement their training and further how they teach. Some become ambassadors for changing the world, while others do not. In the next section of the paper, Section 1.1.2, we outline an argument for testing what we call a teacher enthusiast hypothesis. Building from research on both organisational theory on the institutional perspective and a value-belief-norm model developed in environmental psychology, we argue for testing whether teacher education students' interests in and perceived obligation to teaching about SD before the course interact with a possible change in beliefs, norms and attitudes. That is, we investigate whether the ESD course primarily 
affects teacher education students with a passion for SD issues and a conviction that they should influence pupils to safeguard SD.

\subsubsection{Teachers' Attitudes and Behaviour}

In environmental psychology there is a large literature about how people generate pro-SD beliefs and norms. For several decades, this field of research has been built upon an assumption that pro-environmental behaviour has its roots in personal values. The argument is that many behavioural activities are the result of a causal chain that starts with personal value priorities, which lead to beliefs and the formation of personal norms and behaviour [35,36]. Referred to as the value-belief-norm (VBN) model, values, i.e., general conceptions of the desirable, lead to environmental beliefs (awareness of environmental consequences and responsibility for them), which in the end form personal environmental norms and behaviour [37]. The evidence supporting the validity of the VBN model is quite massive [35,38-45]. In a broad sense, findings from environmental psychology show that pro-environmental norms and behaviour are rooted in a pro-environmental value orientation. Gaining more knowledge on issues concerning SD can have an impact on people's behaviour, but what is critical is whether they initially have pro-environmental norms. To really make an impact on future generations' attitudes and SD behaviour, a key strategy would be to only recruit truly "green" students to teacher education programmes. However, maybe there is more to add to this argument concerning the fact that becoming a teacher also includes possible influences from organizational norms and rules?

At the highest level of abstraction, teachers implement education on a mandate from elected politicians. The teacher is a bureaucrat in the public school system responsible for the education policy output. In an institutional theoretical approach, it is assumed that the organisation of public education influences teachers' attitudes and behaviour [46,47]. That is, the educational organisation, including both the higher education and the public educational systems, influences teachers by setting "rules" for their role as street-level bureaucrats [48]. The institutional theory views the term "rule" in a broad sense, including formal rules (learning and using the national curriculum) as well as informal norms and procedures to which individuals have to adhere. The rules are mediated by discursive processes through which the organisation influences individuals and what is expected of them. The argument put forward is that rules influence bureaucrats by implementing logic of appropriateness, i.e., teacher student and teacher behaviour follows from what they perceive as an appropriate action given the institutional rules surrounding a particular situation. Following the institutional theoretical perspective, teacher education students are to be influenced by the rules and expectations conveyed through mediating from the teacher education programmes. Learning what is anticipated from those entering the public school system they develop beliefs and norms matching these expectations.

In other words, following the VBN model on how people generate personal beliefs and norms, and the perspective from institutional theory on how organisations influence officials, the following (teacher enthusiast) hypothesis can be formulated:

$\mathrm{H}_{2}$ Teacher students who have a strong interest in environmental issues and a conviction that they should influence future students to safeguard SD are more influenced by a teacher ESD course designed to provide the tools needed to teach about SD. 


\section{Design, Data and Measurements}

In order to test our first hypothesis, we designed a field study with two parallel panel data surveys. Following the design in Weiman and colleagues' (2011) [34] studies in higher education physics, using different approaches in parallel physics courses and evaluating the effects, we used panels of students enrolled in courses with different content and practices. The first effort was mapping the degree of variation in the independent variable, i.e., ESD approaches in teacher education programmes. The study consisted of two panels of students in two different teacher education programmes at the University of Gothenburg and University West. During the first semester, the two programmes had similar courses with the exception of a five-week course. This gave us the opportunity to seize the unique naturally occurring variation in two otherwise very similar education programmes. The treatment group at the University of Gothenburg took a course in SD while the control group at University West were given a course on communication and learning. The universities are located in the same region of western Sweden. The University West is located in the city of Trolhattan, almost a suburban town to Gothenburg linked together by a 30 minute commuter train. The surveys were carried out during the same time period in both groups.

Swedish universities organise their teacher education programmes differently. However, there are many similarities in terms of how they organise their curriculum in so-called core educational science courses. These courses are taken by all teacher education students, regardless of age-group focus, and stand for approximately one and a half semesters of the total teacher education programme of 6-11 semesters. At the time of the study, the two universities - the University of Gothenburg and University West-had similar curriculums concerning core educational science courses up until the fourth five-week course in the first semester. The content of the first three courses at both universities was oriented towards (1) basic learning theory, (2) basic scientific theory and educational theory, and (3) social relations. As stated above, in the fourth course of the first semester, the University of Gothenburg offered a course on SD while the students at University West took a course in communication and learning. The similarities in the two teacher education programmes and the change in orientation in the fourth course made the field study design a perfect fit for the study to collect the data. A questionnaire was handed out at the introduction of the two courses when the entire cohorts of students were gathered. As we had only about twenty minutes of the students' and instructors' time, we strived to be as flexible as possible in order to reach large and diverse groups. In order to control for self-selection bias, the students filled out questionnaires before and after the courses. The fact that the courses were given simultaneously made it possible to control for contemporary world events. The survey questions used were centred around five themes in terms of values, beliefs and norms regarding SD [49]: (1) personal moral priorities and pro-environmental orientation, (2) views on SD and responsibility, (3) willingness to contribute to SD, (4) faith in democracy as a solution to SD, and (5) conceptualisation and approaches when it comes to future teaching about ESD.

\subsection{Treatment Group: ESD}

The students in the treatment group participated in a five-week ESD course. The course curriculum stated that the course "highlights the scientific knowledge available to achieve sustainable 
development". The explicit intention of the course is to cover basic values, lifestyles and tools needed to prepare young students to participate in democratic processes, make informed choices and thus contribute to a sustainable society. Particular attention is given to the definition of SD and discussing its three components: social, economic and ecological development. In fact, seven lectures are dedicated to this central element.

The perspectives in the seven lectures originate from different scientific disciplines such as physics, biology, political science and economics. The lectures are followed up in three different teacher-led seminars, where 15-17 students are to problematize the information given in the lectures and the literature. The course also includes three workshops where the students are to develop a didactic theme for ESD. The theme is to address a question of SD from a didactic perspective, thus generating a lesson plan that the teacher students will use in practice in a coming school-based course in the teacher training programme. The syllabus states that "knowledge and training needed for a sustainable future is learning for a SD. This includes preparing children and youth for the coming changes and challenges. The national curriculum supports this approach, i.e., it is not about whether all schools should work with ESD, but rather how they do it". The seminars and workshops are mandatory parts of the course.

\subsection{Control Group: Communication and Learning}

The Communication and Learning course at University West covers how to communicate as a teacher and how to communicate in a learning situation. The curriculum states that the course "demonstrates knowledge of different linguistic expressions as interpretations of reality" and that its purpose is to let students "reflect didactically upon child and adolescent speech, written language and development". The course is also argued to improve the students' individual writing processes, resulting in good proficiency in written Swedish. In the lectures and workshops, the teacher education students learn rhetoric techniques but also writing processes. The course also includes literature seminars on issues such as the use of information and communication technologies among youth and how they are connected to learning and theories of learning. In summary, the control group's course focused on their individual development as communicators and on the challenging position of being a teacher who is to deal with communication in the learning situation on a daily basis.

\section{Results}

\subsection{Participation and the Generation of Pro-SD Beliefs and Norms among the Student Teachers}

In Table 1, we account for the results concerning the first hypothesis, i.e., if participating in a teacher education course designed to provide the tools needed to teach about SD generates any pro-SD beliefs and norms among future teachers. The table shows the mean change among students in the treatment and control groups before and after the courses, as well as the mean difference between the two courses.

Following the order of the questions in Table 1, the first two rows provide evidence of a difference between the treatment group and the control group in terms of moral priorities and pro-environmental orientation. To operationalize moral priorities, the students were asked to what extent they were worried about future pollution and marine environmental damage: not worried at all (1) or very worried (7) (we also asked the same question about unemployment). As shown in Table 1, students 
who participated in the ESD course were significantly more worried about future pollution and marine environmental damages after than before the course. Students in the control group did not increase their level of worrying. It is worth emphasising that, as noted in the third row in Table 1, no change occurred in any of the groups when students were asked about something not related to SD but that nevertheless might be a concern, e.g., unemployment. Table 1 also provides evidence of a significant difference between the groups in terms of a perceived moral obligation to do something about environmental problems. On a scale from do not agree at all (1) to totally agree (7), the students were asked to indicate whether they agreed with the claim that they feel it is a moral obligation to do something about environmental problems. At the end of the two courses, students in the treatment group had increased their sense of moral obligation while students in the control group had not.

Table 1. Changes in beliefs and norms about sustainable development (SD) among future teachers.

\begin{tabular}{|c|c|c|c|}
\hline & \multicolumn{3}{|c|}{ Teacher education programme } \\
\hline & $\begin{array}{c}\text { Treatment } \\
\text { ESD (Univ. Goth) }\end{array}$ & $\begin{array}{c}\text { Control } \\
\text { No ESD (Univ. West) }\end{array}$ & Difference \\
\hline Worrying about future pollution & $\begin{array}{l}+0.13 * \\
\mathrm{n}=323\end{array}$ & $\begin{array}{c}-0.33 * * \\
\mathrm{n}=95\end{array}$ & $\begin{array}{c}+0.46 * * * \\
\mathrm{n}=415\end{array}$ \\
\hline $\begin{array}{l}\text { Worrying about future marine } \\
\text { environmental damage }\end{array}$ & $\begin{array}{c}+0.22 * * * \\
\mathrm{n}=315\end{array}$ & $\begin{array}{l}-0.12 \\
\mathrm{n}=95\end{array}$ & $\begin{array}{l}+0.34 * \\
\mathrm{n}=410\end{array}$ \\
\hline Worrying about unemployment & $\begin{array}{c}0.04 \\
\mathrm{n}=317\end{array}$ & $\begin{array}{c}0.01 \\
\mathrm{n}=96\end{array}$ & $\begin{array}{c}0.03 \\
\mathrm{n}=413\end{array}$ \\
\hline $\begin{array}{l}\text { Moral obligation to do something about } \\
\text { environmental problems }\end{array}$ & $\begin{array}{c}+0.30 * * * \\
\mathrm{n}=322\end{array}$ & $\begin{array}{l}-0.11 \\
\mathrm{n}=97\end{array}$ & $\begin{array}{c}+0.41 * * * \\
\mathrm{n}=419\end{array}$ \\
\hline $\begin{array}{l}\text { I personally should take a lot of } \\
\text { responsibility for SD }\end{array}$ & $\begin{array}{c}-0.03 \\
\mathrm{n}=317\end{array}$ & $\begin{array}{l}-0.16 \\
\mathrm{n}=97\end{array}$ & $\begin{array}{c}-0.14 \\
\mathrm{n}=414\end{array}$ \\
\hline $\begin{array}{l}\text { Willingness to safeguard SD (higher prices, } \\
\text { taxes; reduced standards of living, air travel) }\end{array}$ & $\begin{array}{c}+0.23 * * * \\
\mathrm{n}=315\end{array}$ & $\begin{array}{l}-0.03 \\
\mathrm{n}=96\end{array}$ & $\begin{array}{c}+0.26 * * * \\
\mathrm{n}=411\end{array}$ \\
\hline $\begin{array}{l}\text { How to solve environmental problems. } \\
\text { Democracy is not enough; a more } \\
\text { authoritarian form of government is needed }\end{array}$ & $\begin{array}{c}+0.35 * * * \\
\mathrm{n}=308\end{array}$ & $\begin{array}{l}-0.07 \\
\mathrm{n}=96\end{array}$ & $\begin{array}{l}+0.42 * \\
\mathrm{n}=404\end{array}$ \\
\hline
\end{tabular}

Comments: The first column shows the mean change from before to after the ESD course. The second column shows the change in the programme that did not include the ESD course (paired t-test). The third column shows the difference in mean change (unpaired t-test). The scale in all questions runs from 1 to 7 (for instance: $1=$ not at all worried about climate change, $7=$ very worried about climate change). $*^{*} p 0.10$, $* * p<0.05, * * * p<0.01$.

To operationalize views of responsibility regarding SD, the students were asked to what extent, on a scale from do not agree at all (1) to totally agree (7), they agreed with the claim that they individually should take a lot of responsibility for SD. The results show no difference between the two groups, indicating that most students understand SD to be a collective responsibility (for an overview of mean values for each survey round, see Appendix 1).

On the sixth row of Table 1, we report the students' willingness to contribute to SD. Their willingness was operationalized by asking them how willing they would be, on a scale from not willing (1) to very willing (5), to pay higher prices, higher taxes, accept lower standards of living and 
refrain from air travel to safeguard SD. We once again found a pattern of changes in the treatment group and stable responses in the control group. Students who participated in the ESD course were significantly more willing to contribute to SD after than before the course. Students in the control group did not change their willingness to contribute.

Finally, in the last row of Table 1, the results show a decrease among students in the treatment group concerning faith in democracy as a solution to SD. We asked the students to rate themselves on a scale from do not agree at all (1) to totally agree (7) with the claim that democracy is not enough to prevent serious environmental degradation; a more authoritarian form of government is needed. As noted, there is a significant difference between the two groups. At the end of the courses, the students in the treatment group had decreased their faith in democracy as a solution to SD while there was no change among the students in the control group.

To sum up, our data provide a clear indication that participating in a teacher education course (designed to provide the tools needed to teach about SD) can generate pro-SD beliefs and norms among future teachers. The findings generate a number of interesting thoughts that we will discuss in our concluding remarks. However, before doing so, we will test the so-called teacher enthusiast hypothesis $\left(\mathrm{H}_{2}\right)$ outlined in Section 1.1.2.

\subsection{Environmental Interests and the Safeguarding of SD}

Building from research on both organisational theory and the value-belief-norm model developed in environmental psychology, we tested whether teacher education students' interest in environmental issues and their views on the moral status of influencing pupils when teaching SD before they took the ESD course interact with the likelihood and extent of changes in beliefs, norms and attitudes due to the ESD course. That is, we investigated whether teacher education students who already have an interest in environmental issues and a conviction that they should influence future students to safeguard SD tend to undergo the greatest changes in beliefs, norms and attitudes in connection with the ESD course.

To test the teacher enthusiast hypothesis we used two survey questions. In the first analysis, we used a question concerning the teacher students' general interest in environmental issues $(1=$ not at all interested and $7=$ very interested). In the second analysis, we used a question where the students were asked to what extent they agreed with the claim that it is wrong that schools try to affect students opinions on environmental issues $(1=$ do not at all agree; $7=$ totally agree).

The analyses testing the teacher enthusiast hypothesis were conducted using OLS regression with three variables: ESD course $(1=$ Treatment group, ESD course; $0=$ Control, non ESD), interest in environmental issues $(0=$ scores $1-4, \mathrm{n}=202 ; 1=$ scores $5-7, \mathrm{n}=217)$ and a multiplicative interaction between the two.

As Table 2 demonstrates, there is no significant effect of interest on the relationship between the ESD course and change in beliefs, norms and attitudes among teacher students. Not in any analysis in Model 2 is the interaction variable "ESD course * interest" significant. Thus, we find no support for the hypothesis that teacher education students interested in environmental issues change their beliefs, norms and attitudes the most after a teacher education ESD course. The analysis does, however, show some interesting and significant results. As noted in Model 1, the effect of environmental interest on change in moral priorities and moral obligation is negative while the effect of taking the ESD course is positive. This indicates for instance that when controlling for level of interest in SD, participating in 
the ESD course makes students more worried about environmental issues. On the other hand, we observe that strong initial interest in environmental issues counteracts the effect of the ESD course. Our interpretation is that this is because those with strong initial interest are already more pro-environmental in their attitudes, and hence there is less room left for being influenced by the ESD course [50].

Table 2. Effects of personal interest in environmental issues at $\mathrm{T} 1$ on change in SD beliefs and norms among teacher education students.

\begin{tabular}{|c|c|c|c|c|}
\hline & \multicolumn{2}{|c|}{ Model 1} & \multicolumn{2}{|c|}{ Model 2} \\
\hline \multicolumn{5}{|c|}{ Worrying about global future pollution $(n=417)$} \\
\hline ESD course & $+0.59 * * *$ & $(0.14)$ & $+0.68 * * *$ & $(0.18)$ \\
\hline Interest & $-0.50 * * *$ & $(0.12)$ & -0.38 & $(0.26)$ \\
\hline ESD course ${ }^{*}$ Interest & & & -0.24 & $(0.30)$ \\
\hline Constant & -0.17 & $(0.13)$ & -0.23 & $(0.15)$ \\
\hline Adj. $R^{2}$ & 0.06 & & 0.06 & \\
\hline \multicolumn{5}{|c|}{$\begin{array}{l}\text { Worrying about future marine environmental } \\
\text { damage }(\mathrm{n}=409)\end{array}$} \\
\hline ESD course & $+0.47 * * *$ & $(0.16)$ & $+0.61 * * *$ & $(0.20)$ \\
\hline Interest & $-0.46 * * *$ & $(0.14)$ & -0.18 & $(0.29)$ \\
\hline ESD course $*$ Interest & & & -0.35 & $(0.32)$ \\
\hline Constant & -0.10 & $(0.14)$ & -0.08 & $(0.17)$ \\
\hline Adj. $R^{2}$ & 0.04 & & 0.06 & \\
\hline \multicolumn{5}{|c|}{$\begin{array}{l}\text { Moral obligation to do something about } \\
\text { environmental problems }(n=418)\end{array}$} \\
\hline ESD course & $+0.55 * * *$ & $(0.15)$ & $+0.56 * * *$ & $(0.19)$ \\
\hline Interest & $-0.52 * * *$ & $(0.12)$ & $-0.50 *$ & $(0.27)$ \\
\hline ESD course * Interest & & & -0.03 & $(0.30)$ \\
\hline Constant & -0.05 & $(0.13)$ & -0.05 & $(0.15)$ \\
\hline Adj. $R^{2}$ & 0.05 & & 0.05 & \\
\hline \multicolumn{5}{|c|}{$\begin{array}{l}\text { Willingness to safeguard SD (higher prices, taxes; } \\
\text { reduced living standards, air travel) }(\mathrm{n}=410)\end{array}$} \\
\hline ESD course & $+0.29 * *$ & $(0.09)$ & $+0.28 * * *$ & $(0.11)$ \\
\hline Interest & -0.12 & $(0.08)$ & $-0.13 *$ & $(0.17)$ \\
\hline ESD course $*$ Interest & & & +0.02 & $(0.19)$ \\
\hline Constant & +0.01 & $(0.08)$ & +0.01 & $(0.09)$ \\
\hline Adj. $\mathrm{R}^{2}$ & 0.02 & & 0.05 & \\
\hline \multicolumn{5}{|c|}{$\begin{array}{l}\text { How to solve environmental problems. Democracy } \\
\text { is not enough; a more authoritarian form of } \\
\text { government is needed }(n=403)\end{array}$} \\
\hline ESD course & $+0.46 *$ & $(0.22)$ & +0.56 & $(0.29)$ \\
\hline Interest & -0.08 & $(0.19)$ & +0.13 & $(0.41)$ \\
\hline ESD course $*$ Interest & & & -0.26 & $(0.46)$ \\
\hline Constant & -0.06 & $(0.20)$ & -0.13 & $(0.23)$ \\
\hline Adj. $\mathrm{R}^{2}$ & 0.01 & & 0.01 & \\
\hline
\end{tabular}

Comments: The dependent variable is the difference between the treatment group and the control group in their respective change between $\mathrm{T} 1$ and $\mathrm{T} 2 . \mathrm{N}$ is the number of students included in each analysis and the standard errors are reported in parentheses. ${ }^{*} p<0.10,{ }^{* *} p<0.05, * * * p<0.01$. 
With subdued expectations we also tested the second step of the outlined teacher enthusiast hypothesis. As shown in Table 2, we conducted an identical analysis but instead used the teacher education students' sense of moral obligation towards teaching about SD at T1; see Table 3. To this end, we asked the students to what degree they agreed $(1=$ do not agree; $7=$ totally agree $)$ with the claim that it is wrong for schools to try to affect students' opinions on environmental issues (making a dichotomous variable, $0=$ scores $1-5, \mathrm{n}=105 ; 1=$ scores $6-7, \mathrm{n}=285$, and an interaction between teacher obligation and course). Not too surprisingly, the analysis does not show any significant results, making us even more confident in concluding that the relationship between type of teacher education course and change in beliefs, norms and attitudes among teacher education students is not affected by the students' pre-existing enthusiasm or sense of moral obligation towards teaching about SD.

Table 3. Effects of sense of moral obligation to teach about environmental issues at $\mathrm{T} 1$ on change in SD beliefs and norms among teacher students.

\begin{tabular}{lcccc}
\hline & \multicolumn{2}{c}{ Model 1 } & \multicolumn{2}{c}{ Model 2 } \\
\hline Worrying about global future pollution $(\mathrm{n}=398)$ & & & & \\
\hline ESD course & $+0.47 * *$ & $(0.15)$ & +0.45 & $(0.25)$ \\
Interest & -0.02 & $(0.14)$ & -0.05 & $(0.27)$ \\
ESD course * Interest & & & +0.03 & $(0.32)$ \\
Constant & -0.30 & $(0.16)$ & -0.25 & $(0.21)$ \\
Adj. $\mathrm{R}^{2}$ & 0.02 & & 0.02 & \\
\hline Worrying about future marine environmental & & & & \\
damage (n = 392) & & & & \\
\hline ESD course & $+0.35 * *$ & $(0.01)$ & +0.39 & $(0.27)$ \\
Interest & +0.02 & $(0.14)$ & +0.06 & $(0.30)$ \\
ESD course * Interest & & & -0.06 & $(0.35)$ \\
Constant & -0.11 & $(0.14)$ & -0.14 & $(0.23)$ \\
Adj. $\mathrm{R}^{2}$ & 0.04 & & 0.01 & \\
\hline Moral obligation to do something about & & & & \\
environmental problems (n $=399)$ & & & & \\
\hline ESD course & $+0.41 * * *$ & $(0.15)$ & +0.06 & $(0.25)$ \\
Interest & -0.15 & $(0.14)$ & $-0.54 * *$ & $(0.27)$ \\
ESD course * Interest & & & +0.54 & $(0.32)$ \\
Constant & -0.01 & $(0.16)$ & -0.25 & $(0.21)$ \\
Adj. $\mathrm{R}^{2}$ & 0.01 & & 0.02 & \\
\hline Willingness to safeguard SD (higher prices, taxes; & & & & \\
reduced living standard, air travel) (n=392) & & & & \\
\hline ESD course & $+0.26 * *$ & $(0.09)$ & +0.23 & $(0.15)$ \\
Interest & 0.01 & $(0.08)$ & -0.03 & $(0.13)$ \\
ESD course * Interest & & & +0.05 & $(0.19)$ \\
Constant & 0.02 & $(0.09)$ & +0.01 & $(0.13)$ \\
Adj. $\mathrm{R}^{2}$ & & & & \\
\hline & & & & \\
\hline
\end{tabular}


Table 3. Cont.

\begin{tabular}{lcccc}
\hline & Model 1 & \multicolumn{2}{c}{ Model 2 } \\
\hline $\begin{array}{l}\text { How to solve environmental problems? Democracy } \\
\text { is not enough; a more authoritarian form of }\end{array}$ & & & & \\
government is needed $(\mathrm{n}=385)$ & & & & \\
\hline ESD course & +0.44 & $(0.23)$ & +0.29 & $(0.39)$ \\
Interest & -0.05 & $(0.22)$ & -0.23 & $(0.41)$ \\
ESD course * Interest & & & +0.24 & $(0.48)$ \\
Constant & $-0,05$ & $(0.24)$ & +0.05 & $(0.32)$ \\
Adj. $\mathrm{R}^{2}$ & 0.00 & & 0.00 & \\
\hline
\end{tabular}

Comments: The dependent variable is the difference between the treatment group and the control group in their respective change from $\mathrm{T} 1$ to $\mathrm{T} 2 . \mathrm{N}$ is the number of students included in each analysis and the standard errors are reported in parentheses. ${ }^{*} p<0.10, * * p<0.05, * * * p<0.01$.

The results in this paper show that a course in SD in a teacher education programme can change beliefs, norms and attitudes among teacher students. Without a doubt, the fourth core educational science course of the first semester at the University of Gothenburg, focusing on SD, induces at least a short-term increase in almost all attitudes and perceptions, including moral obligation to do something about SD problems and willingness to (individually) contribute to SD, among the students. The robust unchanged perceptions among students at University West, who at the same time had a course in communication and learning, reinforce the results. Of course, we want to be cautious about asserting long-term effects (and e.g., claiming that all ESD-oriented courses in diverse teacher education programmes would lead to similar results). However, the attitudinal change in the treatment group compared with the stable situation in the control group excludes a so-called Hawthorne-type effect in the study, i.e., that being surveyed by an external research organisation reinforces certain attitudes and types of behaviour. This argument has been outlined in recent research questioning results in observational studies concerning environmental education, arguing that studies might have overestimated intervention effects, hence leading to high expectations on educational policies as a solution to SD among young citizens [51]. Thus, our results lead us to conclude that according to our study, participating in a teacher education course designed to provide the tools needed to teach about SD can generate short-term pro-SD beliefs and norms among future teachers.

\section{Discussions}

Unfortunately, the study does not give us much information about the mechanism behind this change. We can, however, exclude that teacher students' pre-existing interest in environmental issues and sense of moral obligation to teach about SD significantly interact with a change in beliefs, norms and attitudes. Simply, one must not be "truly green" as a future teacher in order to be influenced by an ESD-oriented teacher education course.

What are the policy implications of the result? As initially outlined in this paper, the central idea behind ESD is that the educational system, including the teachers active within it, is a crucial mechanism through which national governments have sought to move beyond what present - primarily regulatory and market-based - systems fall short of achieving. Thus, to form future generations of 
citizens who either voluntarily change their attitudes and SD behaviour or at least accept policies aimed to steer society in a more sustainable direction. In short, our results indicate that teacher education programmes have the potential to respond to these rather heavy expectations from various groupings concerned with SD. Although, some results may indicate that the opinion change is rather extreme, e.g., if an attitude in favour of SD is developed at the expense of a fundamental value as democracy, one may ask whether this is in line with what the government wants. On the other hand, it seems that as the teacher education students develop pro-SD norms, they also change their opinion concerning their influence on pupils. During the ESD course, they increased their support of the claim that schools should not try to affect students' opinions on environmental issues.

Overall, though, the results reveal a somewhat intricate question of whether universities should have the intention to influence future public servants' personal views. A main virtue in educating teachers in Sweden is the ambition to create critical thinkers. What is also sought after is a professional teacher who, within the limits of the regulatory framework, can make autonomous judgments on the basis of common knowledge and ethics. Hence, the aim of a teacher training programme, at least in Sweden, should not be to influence the students in an indoctrinating way, but to provide them with means enabling them to make scientifically sound and ethically well considered decisions.

Being a teacher means having power, and with power comes responsibility. Whether it is desirable that education should be informed by and ought to promote SD is a question that is on the rise in theoretical literature about SD. For instance, the Oxford political theorist and philosopher Simon Caney argues that the problem of climate change does not only impose a responsibility on those with power to mitigate and enable adoption (reducing emissions and maintaining greenhouse gas sinks). Rather, a great deal of responsibility lies with actors (so-called actors of second order responsibilities) with the ability to prevent climate change by affecting the extent to which people can comply actions to counter climate change [52].

If the teacher should have this kind of responsibility, perhaps Sweden and many other countries have embarked on the right track, using higher education such as teacher education to catalyse the necessary norm-based and behavioural changes concerning SD in the next generation.

\section{Conclusions}

The aim of this paper has been to illuminate whether participating in a teacher education course designed to provide the tools needed to teach about SD can generate pro-SD beliefs and norms among future teachers. To investigate this, we performed an effect study of teacher students at Swedish universities. For almost all attitudes and perceptions that we studied, we found positive effects among those students who participated in a SD course compared to students who did not. We also derived a "teacher enthusiast hypothesis" saying that teacher students with a pre-existing intense interest in environmental issues and a conviction that they should influence future students to safeguard SD are more influenced by an ESD course designed to provide the tools needed to teach about SD. Regardless of how we tested the hypothesis, the results indicate no support for it. Despite our critical approach, the results lead us to conclude that a course in SD in a teacher education programme can change SD-related beliefs, norms and attitudes among teacher students. However, these results deserve further attention as the finding that the educational content apparently does affect the students is not 
necessarily a good thing. The finding that the course decreases the treatment students' faith in democracy as a key to SD is a noteworthy example of this. That a course can strengthen the students' belief that democracy is not enough to prevent serious environmental degradation and that a more authoritarian form of government is needed, thus indicate how SD and related issues are presented, discussed and problematized - as well as who is conveying the message-largely determine how the students will respond to the stimuli. To better understand how and under what circumstances ESD affects students, additional studies are required, and one way to improve our understating of the subject is to vary the content of the course in various groups. Furthermore, it is well worth investigating if and how changes in norms and values affect teacher students' willingness to take action for SD as professional teachers. In addition, for our results to be considered more robust, further studies in other contexts are required (do teacher education students in Sweden differ from their counterparts in other countries?). Also, the pre- and post-studies were only conducted five weeks apart. We know very little about the duration of the results, i.e., whether the identified pro-SD beliefs, norms and attitudes last throughout the remainders of the programmes, not to speak of into the students' future careers as teachers. All of this clearly calls for future studies in which also longer term effects are studied.

To sum up, we have discovered that educational achievements can affect students' perceptions and attitudes about SD. However, further research regarding the input (content), throughput (how and by whom) and output (perceptions and attitudes) of the education is very much needed.

\section{Acknowledgments}

The authors would like to thank Adlerbertska stiftelsen for financial support. We also want to thank Daniel Berlin and Niklas Harring for their valuable input and useful comments.

\section{Conflicts of Interest}

The authors declare no conflict of interest.

\section{References and Notes}

1. Lambrechts, W.; Mula, I.; Ceulemans, K.; Molderez, I.; Gaeremynck, V. The integration of competences for sustainable development in higher education: An analysis of bachelor programs in management. J. Clean Prod. 2013, 48, 65-73.

2. Lozano, R.; Lukman, R.; Lozano, F.J.; Huisingh, D.; Lambrechts, W. Declarations for sustainability in higher education: Becoming better leaders, through addressing the university system. J. Clean Prod. 2013, 48, 10-19.

3. With effect studies we refer to controlled (experimentally guided) studies where the aim is to go beyond correlations between dependant and independent variables and carefully and systematically target causality. Adequate causal explanation should give an account for the time order between cause and effect. The intervention should be evaluated in comparative studies to determine if it is more efficacious than other efforts or no effort at all.

4. Dobson, A. Citzenship and the Environment; Oxford University Press: Oxford, UK, 2003. 
5. Dobson, A. Environmental citizenship: Towards sustainable development. Sustain. Dev. 2007, 15, 276-285.

6. Sverige. Kommittén för utbildning för hållbar utveckling. In Att lära för hållbar utveckling [elektronisk resurs]: Betänkande (in swedish); Fritzes offentliga publikationer: Stockholm, Sweden, 2004; p. 186.

7. Regeringen. Strategiska utmaningar-en vidareutveckling av svensk strategi för hållbar utveckling (in Swedish); Regeringskansliet: Stockholm, Sweden, 2005.

8. Rickinson, M. Learners and learning in environmental education: A critical review of the evidence. Environ. Educ. Res. 2001, 7, 207-320.

9. Organisation for Economic Co-operation and Development (OECD). Green at fifteen? How 15-Year-Olds Perform in Environmental Science and Geoscience in Pisa 2006; OECD: Paris, 2009; p. 115.

10. Hart, P.; Nolan, K. A critical analysis of research in environmental education. Stud. Sci. Educ. 1999, 34, 1-69.

11. Östman, L. Nationell och internationell miljödidaktisk forskning: En forskningsöversikt (in Swedish). Available online: http://uu.diva-portal.org/smash/record.jsf?pid=diva2:109806 (accesed on 18 October 2013).

12. Skolverket. Nationella utvärderingen av grundskolan 2003. Huvudrapport- naturorienterande ämnen, samhällsorienterande ämnen och problemlösning $i$ årskurs 9 (in Swedish); Skolverket: Stockholm, Sweden, 2004.

13. Coertjens, L.; Pauw, J.B.-D.; de Maeyer, S.; van Petegem, P. Do schools make a difference in their students' environmental attitudes and awareness? Evidence from pisa 2006. Int. J. Sci. Math. Educ. 2010, 8, 497-522.

14. Taskin, O. The environmental attitudes of turkish senior high school students in the context of postmaterialism and the new environmental paradigm. Int. J. Sci. Educ. 2009, 31, 481-502.

15. Öhman, J. The Ethical Tendency in Education for Sustainable Development-a Practical Understanding of Meaning-Making; Örebro University: Örebro, Sweden, 2006.

16. Svennbeck, M. Omsorg om naturen: Om no-utbildningens selektiva traditioner med fokus på miljöfostran och genus (in Swedish); Acta Universitatis Upsaliensis: Uppsala, Sweden, 2003; p. 268.

17. Östman, L. Education for sustainable development and normativity: A transactional analysis of moral meaning-making and companion meanings in classroom communication. Environ. Educ. Res. 2010, 16, 75-93.

18. Kronelid, D. Ecofeminism and Environmantal Ethics, an Analysis of Ecofeminist Ethical Theory; Uppsala Universitet: Uppsala, Sweden, 2003.

19. Stenmark, M. Miljöetik och miljövård. Miljöfrågornas värderingsmässiga dimension (in Swedish); Studentlitteratur: Lund, Sweden, 2000.

20. Floden, R.E. Research on Effects of Teaching: A Continuing Model for Research on Teaching. In Handbook on Research on Teaching; Richardson, V., Ed.; American Educational Research Association: Washington, DC, USA, 2001.

21. Medley, D.M.; Mitzel, H.E. Measuring Classroom Behavior by Systematic Observation. In Handbook of Research on Teaching; Gage, M.L., Ed.; Rand Mc Nally: Chicago, IL, USA, 1963. 
22. Lagemann, E.C. An Elusive Science: The Troubling History of Education Research; University of Chicago Press: Chicago, IL, USA, 2002.

23. Brown, A.L. Design experiments: Theoretical and methodological challenges in creating complex interventions in classroom settings. J. Learn. Sci. 1992, 2, 141-178.

24. Cobb, P. Conducting Teaching Experiments in Collaboration with Teachers; Lawrence Erlbaum Associates Inc.: Mahwah, NJ, USA, 2000.

25. Yoshida, M.; Fernandez, C. Lesson Study: A Japanese Approach to Improving Mathematics Teaching and Learning; Routledge: London, UK, 2004.

26. Lewis, C.C.; Perry, R.R.; Hurd, J. Improving mathematics instruction through lesson study: A theoretical model and north american case. J. Math. Teach. Educ. 2009, 12, 285-304.

27. Marton, F.; Tsui, A.B.; Chik, P.P.; Ko, P.Y.; Lo, M.L. Classroom Discourse and the Space of Learning; Routledge: London, UK, 2013.

28. Ingerman, A.; Linder, C.; Marshall, D. The learners' experience of variation: Following students' threads of learning physics in computer simulation sessions. Instr. Sci. 2009, 37, 273-292.

29. Björneloo, I. Innebörder av hållbar utveckling : En studie av lärares utsagor om undervisning (in Swedish); Göteborgs Universitet: Göteborg, Sweden, 2007.

30. Jonsson, G. Mångsynthet och mångfald: Om lärarstudenters förståelse av och undervisning för hållbar utveckling (in Swedish); Institutionen för utbildningsvetenskap, Luleå Tekniska Universitet: Luleå, Sweden, 2007.

31. Sund, P. Att urskilja selektiva traditioner i miljöundervisningens socialisationsinnehåll—implikationer för undervisning för hållbar utveckling (in Swedish); Mälardalen University Press: Västerås, Sweden, 2008.

32. Knutsson, B. Curriculum in the Era of Global Development-Historical Legacies and Contemporary Approaches (in Swedish); Acta Universitatis Gothoburgensis: Gothenburg, Sweden, 2011.

33. Kaasila, R.; Hannula, M.; Laine, A.; Pehkonen, E. Socio-emotional orientations and teacher change. Educ. Stud. Math. 2008, 67, 111-123.

34. Deslauriers, L.; Schelew, E.; Wieman, C. Improved learning in a large-enrollment physics class. Science 2011, 332, 862-864.

35. Stern, P.C. Towards a coherent theory of environmentally significant behavior. J. Soc. Issues 2000, 56, 407-424.

36. Stern, P.C.; Dietz, T.; Abel, T.; Guagnano, G.A.; Kalof, L. A value-belief-norm theory of support for social movements: The case of environmentalism. Hum. Ecol. Rev. 1999, 6, 81-97.

37. Schwartz, S. Universals in the content and structure of values: Theoretical advances and empirical tests in 20 countries. Adv. Exp. Soc. Psychol. 1992, 25, 1-65.

38. Harring, N.; Jagers, S.C. Should we trust in values? Explaining public support for pro-environmental taxes. Sustainability 2013, 5, 210-227.

39. Jagers, S.C.; Martinsson, J.; Matti, S. Ecological citizenship: A driver of pro-environmental behavior? Env. Polit. 2013, doi:10.1080/09644016.2013.835202.

40. Jagers, S.C.; Matti, S. Ecological citizens: Identifying values and beliefs that support individual environmental responsibility among Swedes. Sustainability 2009, 2, 1055-1079. 
41. Hansla, A.; Gamble, A.; Juliusson, A.; Gärling, T. The relationship between awareness of consequences, environmental concern, and value orientations. J. Environ. Psychol. 2008, 28, 1-9.

42. Eriksson, L.; Garvill, J.; Nordlund, A. Interrupting habitual car use: The importance of car habit strength and moral motivation for personal car use reduction. Transport. Res. F 2008, 11, 10-23.

43. Dietz, T.; Fitzgerald, A.; Shwom, R. Environmental values. Annu. Rev. Environ. Resour. 2005, 30, 335-372.

44. Steg, L.; Drejjerink, L.; Abrahamse, W. Factors influencing the acceptability of energy policies: A test of vbn theory. J. Environ. Psychol. 2005, 25, 415-425.

45. Nordlund, A.; Garvill, J. Value structures behind proenvironmental behavior. Environ. Behav. 2002, 34, 740-756.

46. March, J.G.; Olsen, J.P. Rediscovering Institutions: The Organizational Basis of Politics; Free Press: New York, NY, USA, 1989.

47. Lipsky, M. Street-level bureaucracy: Dilemmas of the Individual in Public Services; Russell Sage Foundation: New York, NY, USA, 2010.

48. Fredriksson, A. Marknaden och lärarna: Hur organiseringen av skolan påverkar lärares offentliga tjänstemannaskap (in Swedish); Statsvetenskapliga Institutionen, Göteborgs Universitet: Göteborg, Sweden, 2010.

49. Matti, S. Exploring Public Policy Legitimacy: A Study of Belief-System Correspondence in Swedish Environmental Policy. Ph.D. Thesis, Luleå University of Technology, Luleå, Sweden, 2009.

50. For that reason we also made analysis reversing the variable "interests in environmental issues", i.e., we investigated whether teacher students who did not have an interest in environmental issues was the ones that underwent greatest changes as to beliefs, norms and attitudes after the ESD-course. The analysis did however not show any significant results concerning the interaction variable ESD course * reversed interest.

51. Goodwin, M.J.; Greasley, S.; John, P.; Richardson, L. Can we make environmental citizens? A randomised control trial of the effects of a school-based intervention on the attitudes and knowledge of young people. Environ. Polit. 2010, 19, 392-412.

52. Caney, S. Two kinds of climate justice-avoiding harm and sharing burdens. J. Polit. Philos. 2014, 22, in press.

\section{Appendix}

Appendix 1. Mean change in treatment and control group.

\begin{tabular}{|l|c|c|c|c|c|c|}
\hline \multirow{2}{*}{} & \multicolumn{4}{|c|}{ Teacher education programme } \\
\cline { 2 - 7 } & \multicolumn{3}{|c|}{$\begin{array}{c}\text { Treatment } \\
\text { ESD (Univ. Goth) }\end{array}$} & \multicolumn{4}{c|}{$\begin{array}{c}\text { Control } \\
\text { No ESD (Univ. West) }\end{array}$} \\
\cline { 2 - 7 } & $\mathbf{T 1}$ & $\mathbf{T 2}$ & Diff & T1 & T2 & Diff \\
\hline Worrying about future pollution & 5.47 & 5.60 & $\begin{array}{c}+0.13 * \\
\mathrm{n}=323\end{array}$ & 4.81 & 4.48 & $\begin{array}{c}-0.33 * * \\
\mathrm{n}=95\end{array}$ \\
\hline $\begin{array}{l}\text { Worrying about future marine } \\
\text { environmental damage }\end{array}$ & 5.30 & 5.52 & $\begin{array}{c}+0.22 * * * \\
\mathrm{n}=315\end{array}$ & 4.40 & 4.27 & $\begin{array}{c}-0.13 \\
\mathrm{n}=95\end{array}$ \\
\hline
\end{tabular}


Appendix 1. Cont.

\begin{tabular}{|l|c|c|c|c|c|c|}
\hline \multirow{2}{*}{} & \multicolumn{5}{|c|}{ Teacher education programme } \\
\cline { 2 - 7 } & \multicolumn{3}{|c|}{$\begin{array}{c}\text { Treatment } \\
\text { ESD (Univ. Goth) }\end{array}$} & \multicolumn{3}{c|}{$\begin{array}{c}\text { Control } \\
\text { No ESD (Univ. West) }\end{array}$} \\
\cline { 2 - 8 } W1 & T2 & Diff & T1 & T2 & Diff \\
\hline Worrying about unemployment & 4.74 & 4.78 & $\begin{array}{c}0.04 \\
\mathrm{n}=317\end{array}$ & 4.72 & 4.73 & $\begin{array}{c}0.01 \\
\mathrm{n}=96\end{array}$ \\
\hline $\begin{array}{l}\text { Moral obligation to do something about } \\
\text { environmental problems }\end{array}$ & 5.17 & 5.47 & $\begin{array}{c}+0.30 * * * \\
\mathrm{n}=322\end{array}$ & 4.49 & 4.38 & $\begin{array}{c}-0.11 \\
\mathrm{n}=97\end{array}$ \\
\hline $\begin{array}{l}\text { I personally should take a lot of } \\
\text { responsibility for SD }\end{array}$ & 5.86 & 5.83 & $\begin{array}{c}-0.03 \\
\mathrm{n}=317\end{array}$ & 5.43 & 5.27 & $\begin{array}{c}-0.16 \\
\mathrm{n}=97\end{array}$ \\
\hline $\begin{array}{l}\text { Willingness to safeguard sustainable } \\
\text { development (higher prices, taxes; reduced } \\
\text { living standard, air travel) }\end{array}$ & 3.20 & 3.43 & $\begin{array}{c}+0.23 * * * \\
\mathrm{n}=315\end{array}$ & 2.82 & 2.79 & $\begin{array}{c}-0.03 \\
\mathrm{n}=96\end{array}$ \\
\hline $\begin{array}{l}\text { How to solve environmental problems. } \\
\text { Democracy is not enough; a more } \\
\text { authoritarian form of government is needed }\end{array}$ & 3.85 & 4.20 & $\begin{array}{c}+0,35 * * * \\
\mathrm{n}=308\end{array}$ & 3.84 & 3.77 & $\begin{array}{c}-0.07 \\
\mathrm{n}=96\end{array}$ \\
\hline $\begin{array}{l}\text { Personal interest in environmental issues } \\
\text { Penools should not try to affect students' }\end{array}$ & 4.79 & 4.95 & $\begin{array}{c}+0.16 * * \\
\mathrm{n}=321\end{array}$ & 3.94 & 3.86 & $\begin{array}{c}-0.08 \\
\mathrm{n}=96\end{array}$ \\
\hline $\begin{array}{l}\text { Schinions on environmental issues } \\
\text { oping }\end{array}$ & 2.06 & 3.19 & $\begin{array}{c}+1.13 * * * \\
\mathrm{n}=295\end{array}$ & 2.54 & 2.83 & $\begin{array}{c}+0.29 \\
\mathrm{n}=89\end{array}$ \\
\hline
\end{tabular}

${ }^{*} p<0.10,{ }^{* *} p<0.05,{ }^{* * *} p<0.01$.

(C) 2013 by the authors; licensee MDPI, Basel, Switzerland. This article is an open access article distributed under the terms and conditions of the Creative Commons Attribution license (http://creativecommons.org/licenses/by/3.0/). 